卒後教青セミナー 1

\title{
胆管切開切石術の手技
}

\author{
日本医科大学第 1 外科 \\ 三 樹 勝
}

\section{OPERATIVE PROCEDURE OF CHOLEDOCHOLITHOTOMY}

\section{Masaru MIKI}

First Department of Surgery, Nippon Medical School

乗引用語：胆管結石, 総胆管切開切石術, 十二指腸上部総胆管切開術

胆石症の基本的手術は胆襄剔出術と胆管切開切石術 である。これらの手術手技そのものの原理は決して複 雑なものではなく，わかりやすく簡明であるにもかか わらず，手術操作を加觉る局所が深部のせをいところ であるのに加えて，結石とともに炎症が存在すると病 変部の解剖的関係がわからなくなって術者を困惑せし めることもしばしばである．その上胆道系には血管， 胆管の走行異常や畸型が多く,粗暴な手術操作は出血, 胆管損傷など思わぬ事故を引き起こす危険があり，ひ とたびこのようなことが起こるとその修復に極めて難 涉するので，注意深い操作が肝要である．再手術とな ると合併症の頻度も高く, 手術成績も悪くなり, その 予後も決して芳しくない，注かの領域の手術にもまし て, 胆道手術では“この 1 回の手術が勝負”といら気構 えで臨さべきであろう。

本稿では胆亳をすでに摘出したあと，総胆管をいか に切開し，結石を摘出するかの手技をわれわれの教室 で行っている方法を中心に述べる.

総胆管切開切石術 (choledocholithotomy) は総胆管 切開術 (choledochotomy) と, 切石法 (lithotomy) (以前は截石法と言っていた)の組み合せより成ってい る. 総胆管切開術には切開する場所ないし経路によっ $\tau$, 十二指腸上部総胆管切開術 (supraduodenal choledochotomy), 十二指腸後部総胆管切開術 (retroduodenal choledochotomy), 経十二指腸総胆管 切開術（transduodenal choledochotomy）の 3 つに分 けられるが，通常最も多く行われ，外科医として習熟

\footnotetext{
*第 3 回卒後教育七 ミナー・胆管結石の治療

$<1983$ 年10月18日受理 > 別刷請求先 : 三樹 勝

₹113 文京区干駄木 $1-1-5$ 日本医科大学第 1

外科
}

乙ておくべきものは十二指腸上部総胆管切開術であ り，ここに述べる手技す本法に関するすのである．な 扣肝内結石の手術は考方方，手技も異るので省略した。

\section{1. 腹壁の切開 (図 1)}

多種多様のものが挙げられており,一般には上腹部 正中切開 upper midline incision, Kehr の波状切開1) Wellenschnitt, Mayo-Robson の肋骨弓縁腹直筋外縁 切開2)（ホッケー杖切開 hockey stick incision），ある いはKochr の右肋骨弓縁切開3) (subcostal oblique incision)などが用いられており，最も多いのは上腹部 正中切開法であるよらであるが45)，われわれの教室で はいわゆる坬状切開 Bogenschnitt と呼ばれる皮切を 好んで用いている。これは Masson 切開2の皮切に似 ているが，剣状突起下ょり脐窝右 $4 \sim 5 \mathrm{~cm}$ 側方に向っ て孤状の皮切を加兄, 腹直筋の筋䩱前葉を緃に切開し て腹直筋を筋鈎で左右に鈍に裂いて筋輀後葉に達し, それから腹膜を開く経腹直筋切開法である，上部では

図 1 腹壁の切開

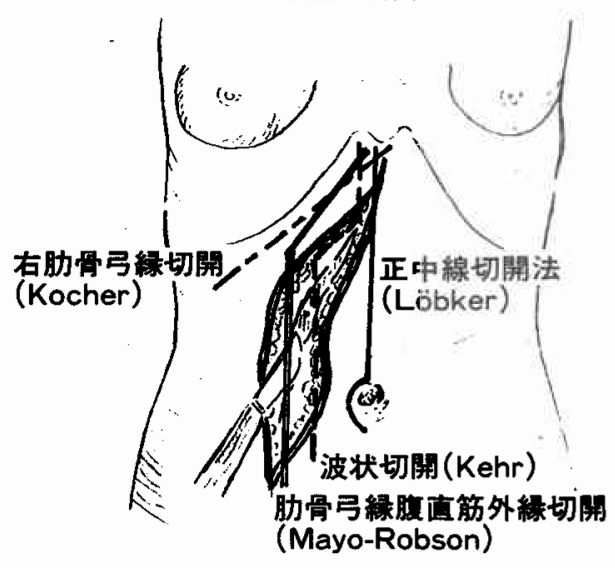


一部斜切開になるので，一部腹直筋を切断することに なる.この切開法は時間がかかるとか, 出血量が多く なる, あるいは一部血管, 神経, 筋の損傷, 切断をと るならなどの問題点があげられているが，大さな視野 で, 病変部を楽に露出できること, 術後の腹壁へルニ ヤが発生しにくいなどの利点がある.

\section{2. 総胆管への到達，露出と触診（図 2）}

胆囊を摘出したあと, 肝十二指腸間膜を緊張せしめ, 左手の示指と中指をWinslow 孔に挿入し, 間膜の右 寄りの前面を拇指との間で触知すれば総胆管を見出す ことは左程困難なことではない.問題は再手術患者の 場合である，繁着が高度であるばかりか, 解剖的位置 が変ってここまで到達するのに難渋することがしばし ばである。通常胃幽門部や十二指腸起始部が肝下面か ら肝十二指腸膜前面にかけて強固に瘾着していること が多いので, 肝の遊離縁から肝下面に向ってこれらと の㽷着を豩離し，ある程度肝十二指腸間膜の所在が確 められたらそれ以上の剝離操作を中止し，今度は一転 して下方ょりの到達経路として結腸訮弯曲部の边りか ら横行結腸の走行をたよりにこれを肝下面, 後腹膜か ら剥がすようにして十二指腸下行脚の外側部へと達 し，これを上行性にたとっって Winslow 孔，肝十二指腸 間膜へと達するよらにする，症着の别離を上手にすす めるコッとして, 生食水を $21 \mathrm{G}$ 程度の注射針を用いて 漫潤せしめ粗となった組織間吵をクーパー氏剪刀を用 いて或るときは切離し，あるときは押し剝がすように して剶離をすすめると容易である. 肝十二指晹間膜前 面と痰着していることの多い十二指腸起始部との間の

因 2 総胆管の触診

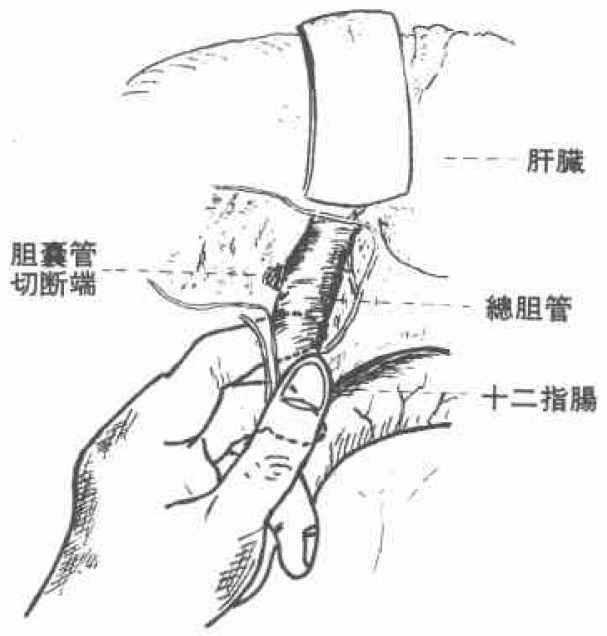

剝離にはとくに細心の注意を払い十二指腸の損傷をき たさないようにする. Winslow 孔より入れた左手の示 指と拇指との間に総胆管を挾んだら結石の有無を検索 するが，䏝内胆管，ことに末端部の小結石の確認のた めには, Kocher の十二指腸授動術を行って荤頭・十二 指腸乳頭部附近を左手示指，中指と拇指との間で挾む ようにつかんで，指先に神経を集中させ触診すると見 逃すことが少ない。

3. (上十二指腸) 胆管切開と切石法（図 3，4） 棇胆管切開を行うか否かの適応は松倉 ${ }^{6)}$, 三宅ら ${ }^{4)}$ 昔 から多数の見解が示されている。これらを列挙してみ ると,

1）総胆管内に結石を触知しらる場合

2）総胆管内に結石の存在が疑われる場合

3）総胆管の拡張 (直径 $10 \mathrm{~mm}$ 以上) 肥厚の認められ る場合

4）現在黄㾝があってしかる疼痛発作を伴う場合

図 3 総胆管の切開法

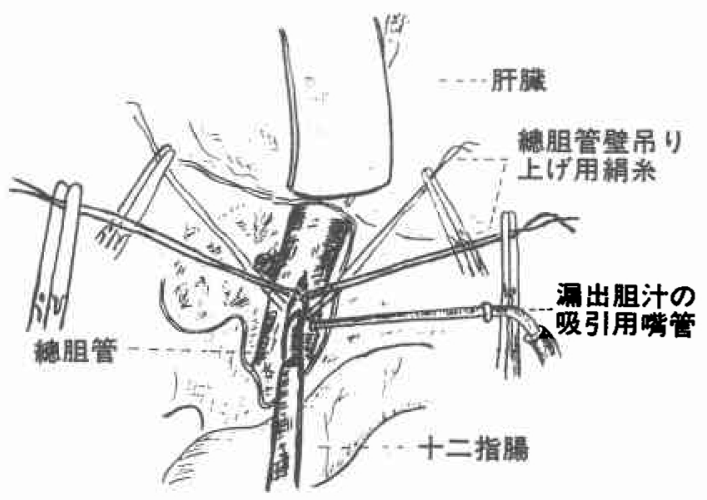

図 4 胆管結石の摘出法

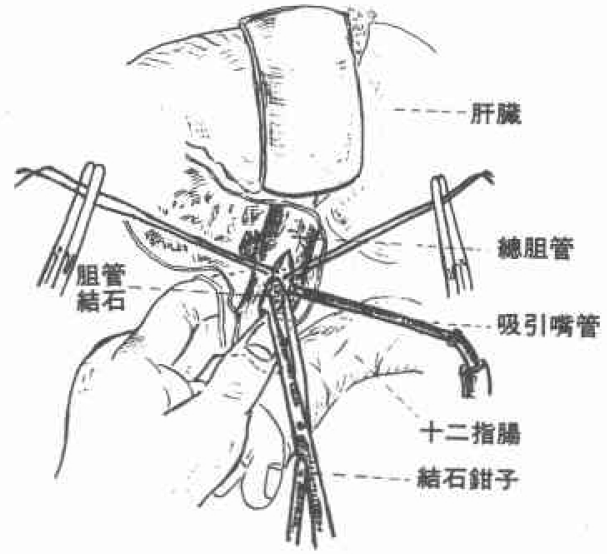


5）既往に黄疸と疼痛発作のある場合

6）頻回の胆石症発作のある場合

7）胆亭内に小結石の存在する場合, ことに多数の結 石のある場合

8）胆霊管切断端に結石あるいは胆砂の存在する場 合

9）胆垩が萎縮している場合

10）胆管炎のある場合

11）肝の硬変の証明される場合

12）荤の硬変または资症の存する場合

13）総胆管内に蜔虫迷入，などの場合

これらの適応項目をみると不確定要素を含んだもの がかなり見られる、結石の存在が確認されていない場 合でも疑わしい場合には踌躇することなく開けてみろ ということであるが，今日では術前の検索でほとんど 微細な点まで胆道の病態を把握しらるので, 術中に切 開すべきか否かを迷らことは少ない。

総胆管を切開するときには，胆管壁と思われるとこ ろに 2 本の綟系をかけ，これをつり上げるように助手 に保持せしめ,この間でまず試験穿刺を行い, 胆汁が 吸引されることを確める。どんなに確実と思われても この操作を行うことが思わね pitfall に陥入るのを防 ぐことになる，吸引した胆汁は色調，とくに混濁の有 無をみると炎症, 結石の有無判断の材料となる。胆汁 は細菌学的検索, 細胞診などに供する。

次いで切開を加光るが，一度に大きく切ることは胆 汁の涌出を招き手術野を污染することとなるので，ま ず最初は注意深く小切開を加克，涌出する胆汁を助手 に吸引せしめつつ, 小切開口から胆管壁の全層を通し てさらに 2 本の綟糸をかけ，これをつり上げるように 第 2 助手 (患者左側, 頭側に位置)，第 3 助手 (患者右 側，術者の左側に位置）にそれぞれ軽く保持せしめつ つ切開口を切り拡げる。

次の操作としての切石法には，(1) 胆石鈿子でつか みあげてくる方法，(2）大小の胆石匙で搔きあげてく る方法，（3）生食水を一気に注入して噴出して溢れ出 てくる匠とともに結石を洗い出す操作を何回となく繰 り返す洗涤法，(4)胆道ファイバーでバスケット鉗子な どを用いて摘出する方法などがあるが，大部分の症例 では（図 4) に示すごとく，Winslow 孔に㨀入した手 指を上手に使って結石を切開口近くまで移動させ，左 示指の先端で結石を切開口に向って押し上げるよらな 操作を加えながら，胆石鉗子で結石をはさみ取ること ができる，要は結石を遺残することのないよう心掛け
ることであるが，最近では術後も T字管瘦孔より容易 に遣残結石を摘出しらる気安さからか，ややむすると 術中における遺残結石有無の検索が蹯かになりがちの 傾向があり，厳に戒しむべきであろら，遺残結石有無 の検索には術中胆道造影，術中胆道ファイバーなどが 駆使されているが，昔から行われているゾンデによる 触知法に習熟しておくことが基本的に必要であるばか クか，確率む極めて高い，胆石ゾンデは材質が軟らか

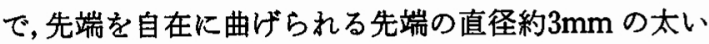
ものを用らるとよく，細くて，材質の硬いものは極め て危険である．このゾンデを胆管の走行に合せて任意 に弯曲せしめ，下流の方は胆管末端部より乳頭部をこ えて十二指腸まで，上流の方は肝内胆管に至るまで検 索するが(図 5)，ゾンデはごく軽く把持することが重 要なコッの一つで，これを上下に動かすと，結石に当 つたときに他人にはわからない微妙な手ごたえが感じ とられ，またゾンデにより総胆管の走行がよく判るば

\section{図 5 ゾンデを用いた遺残結石有無の検索}

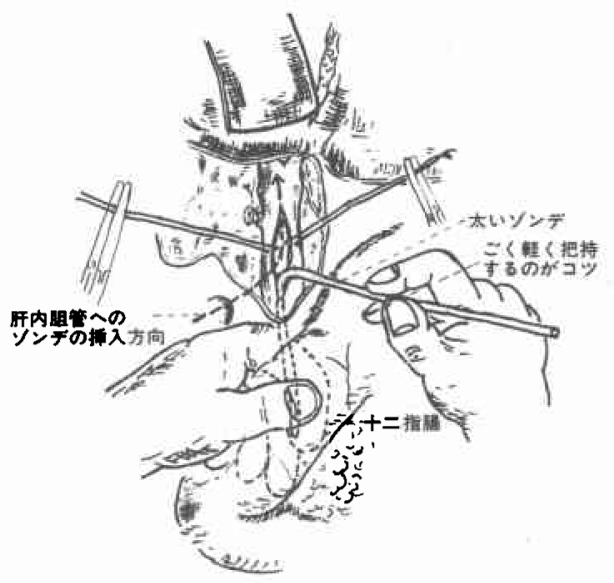

図 6 総胆管切開口の䋖合閉鎖

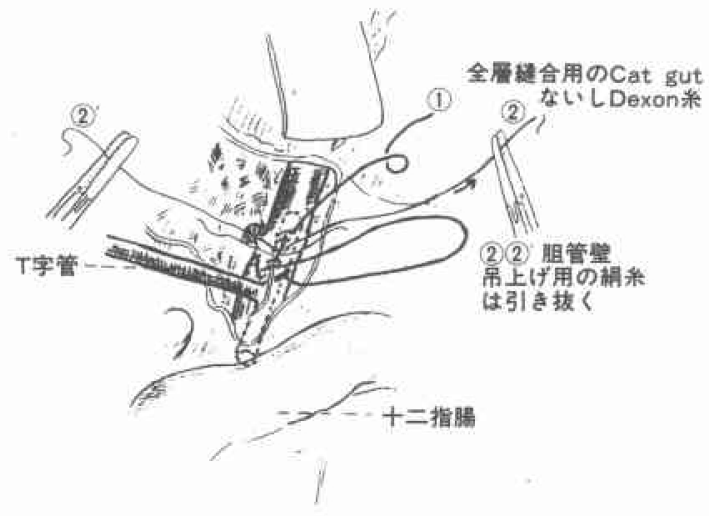


かりでなく，このゾンデに沿って総胆管をよく触知す ると，小さな石まです触れることができ，見逃すこと が少なくなる、このゾンデをきつく持つて，ゴシゴシ しごいたために知らぬ間に腪内胆管を十二指腸後壁ま で貫通し, 合併症のためにその後の処置に四苦八苦し た最近の教室例経験がある。 またゾンデによる検索に 際しては十二指腸授動術を行って, 膵頭部, 十二指腸 後面に㨀入した左手示指, 中指の先端とゾンデの検索 との連係操作を上手に行うこともコッの一つである.

\section{4. 総胆管切開口の链合閉鎖, ドレナージ（図 6 ）}

結石の摘出後 T字管を挿入しないで総胆管切開口を 一次的に縫合閉鎖する場合は, )1) コ系石で数も 1 〜2 箇, 肝内結石を含めた遺残結石がないことが確実 なとき，(2）乳頭部に㢸窄がない，(3)胆道の炎症所見 が全くみられない，など条件が整っているときで， 通常はT字管を㨀入して切開口を縫合閉鎖している. 縫合系は吸収性の材料を用いることが大切で，以前は 綿糸を用いたためにこれが核となって結石の再発をみ たといら報告47)がよく見られ，教室でも経験してい る 。るず胆管壁の全層を Catgut, Dexon, 最近では coated vicryl (ポリグラクチン910)のごとき释合糸で 連続縫合する，胆管の細い場合は結節縫合を行ってい る、さらに絹系で 2 層縫合を行うことが多いが，一層 縫合でも十分である。最後にドレナージ管を右側腹部 より肝床部, Winslow 孔近くまで挿入しているが，ど んなに自信に満ちた手術をしたと思っても, 胆道系に
は畸型も多く，万がーといらことも考慮して行らよう にしている，1本のドレナージが命網となって助かっ たという释験をすたない胆道外科医はいないであろ 5. 肝床部，肝十二指腸間膜前面には大網をひっくり 返して覆らように括いて腹壁を縫合閉鎖する。な打 $\mathrm{T}$ 字管は後日胆道ファイバーを挿入しなければならない ようなことが起こりらることも考虑して，腹壁に向っ て直角に最短距離で体外に誘導固定することが望まし い.

\section{文 献}

1) Kehr $\mathrm{H}$ : Über der Bauchdeckenschnitt, die Bauchnaht und die Tamponade bei Gallensteinoperationen. Arch Klin Chir $97: 74,1912$

2) Madden JL: Atlas of Technics in Surgery. Appleton-century. Crofts, New York, 1958

3) Kocher $T$ : Textbook of operative surgery. Translation from the second German edition by J Harold, Stiles, London, 1895 (Moore HG), Surgery $35: 440,1954$

4）三宅 博：胆石症。東京, 金原出版, 1970, p472

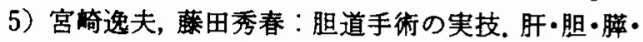
脾手術のすべて, 3, 東京, 金原出版, 1982, p1

6）松合三郎：胆石症. 臨床外科全書第 4 巻 (II)，東 京, 金原出版, 1966, p402

7) Millbourn EW : On reoperation for cholelithiasis. Acta Chir Scand 99 : 285-312, 1949-50

8）田中次男：輸胆管切開部释合系を核とした䏣石再 発の 2 症例について。臨外 $13: 195-198,1958$ 